Soleh, M.A. · T.A Sirait · M. Ariyanti · S. Rosniawaty

\title{
Respons fisiologis dan agronomis bibit kopi pada kerapatan naungan yang berbeda
}

Sari Tanaman kopi seringkali dibudidayakan di areal hutan, dimana terdapat tanaman tahunan seperti pepohonan yang terus tumbuh sehingga menurunkan intensitas cahaya yang jatuh ke tanaman kopi. Hal ini menjadi masalah bagi pertumbuhan dan perkembangan tanaman kopi yang dinaungi pohon tersebut. Penelitian ini bertujuan untuk menguji fisiologis dan agronomis dua kultivar kopi dalam intensitas naungan yang berbeda untuk mendapatkan informasi kultivar kopi yang terbaik. Percobaan dilaksanakan dari bulan Maret hingga Juni 2020 di Kebun Percobaan Ciparanje, Fakultas Pertanian, Universitas Padjadjaran, Jatinangor, Sumedang, Jawa Barat. Percobaan menggunakan Rancangan Petak Terbagi (Split plot) dengan dua faktor dan diulang sebanyak tiga kali. Taraf dari main plot adalah tanpa naungan, naungan paranet $50 \%, 60 \%, 70 \%$, dan $80 \%$, sedangkan taraf dari sub plot adalah kultivar Lini S 795 dan Sigararutang. Hasil penelitian menunjukkan tidak terdapat pengaruh interaksi antara naungan dan kultivar. Penggunaan naungan $70 \%$ memberikan pengaruh terbaik terhadap tinggi bibit kopi dan suhu daun, serta kultivar Lini S 975 memberikan pengaruh terbaik terhadap tinggi bibit kopi, luas daun, indeks klorofil, klorofil fluoresens dan suhu daun.

Kata kunci: Kopi · Lini S 795 Klorofil fluorescence · Sigararutang

\section{Physiological and agronomical responses of coffee seedlings under different shade densities}

\begin{abstract}
Cultivation of coffee tree in forest areas, where the wooden trees grew previously, it will be causing in decreasing of light intensity that is falling into the ground as long as trees canopy development leading to shade of coffee trees, this is affecting coffee tree growth and development. The objective of this study was to evaluate physiologically and agronomically of two coffee seedling cultivars under net shading densities. The experiment was conducted at Ciparanje Experimental Station, Faculty of Agriculture, Padjadjaran University, Jatinangor, Sumedang, West Java, from March to June 2020. Experimental design used in this research was split plot with two factors and three replications. The main plot was the shading densities which consisted of five levels, namely without shade $0 \%$, net shade $50 \%, 60 \%, 70 \%$, and $80 \%$. The subplot was the coffee cultivars, consisted of two levels, namely Lini S 795 cultivar and Sigararutang. All parameters was not indicated any interaction. The results showed that the $70 \%$ shade gave the best effect on plant height and leaf temperature. Lini S 795 cultivar gave the best effect on plant height, leaf area, chlorophyll index, chlorophyll fluorescence, and leaf temperature.
\end{abstract}

Keywords: Coffee · Chlorophyll fluorescence · Lini S 795 • Net shading · Sigararutang

Diterima : 4 Juni 2021, Disetujui : 28 Juli 2021, Dipublikasikan : 1 Agustus 2021

DOI: https:// doi.org/10.24198/kultivasi.v20i2.32882

\footnotetext{
Soleh, M.A. ${ }^{1}$ T.A Sirait ${ }^{2} \cdot$ M. Ariyanti ${ }^{1} \cdot$ S. Rosniawaty ${ }^{1}$

${ }^{1}$ Department of Agronomy, Faculty of Agriculture, Universitas Padjadjaran,

${ }^{2}$ Mahasiswa Program Studi Agroteknologi, Fakultas Pertanian Universitas Padjadjaran.

Korespondensi: m.arief@unpad.ac.id
} 


\section{Pendahuluan}

Kopi merupakan salah satu komoditas sektor perkebunan yang memiliki peran penting bagi perekonomian negara. Indonesia merupakan produsen kopi terbesar keempat di dunia setelah negara Brazil, Vietnam, dan Kolombia (Sekretariat Jendral Perkebunan, 2016). Volume ekspor kopi Indonesia meningkat pada tahun 2012 sebesar 448.591 ton dengan total nilai sebesar US\$ 1.249 .520 menjadi 467.800 ton dengan total nilai sebesar US\$ 1.187 .157 pada tahun 2017, demikian juga dengan total luas areal lahan dari tahun 2012 seluas 1.235.289 ha meningkat sebanyak 1.251 .703 ha pada tahun 2017 (Badan Pusat Statistik, 2018).

Pada tahun 2012, produktivitas kopi di Indonesia mencapai $761 \mathrm{~kg} /$ ha dan menurun di tahun 2017 menjadi $704 \mathrm{~kg} / \mathrm{ha}$ (Direktorat Jenderal Perkebunan, 2018). Sebagian besar lahan kopi diusahakan oleh perkebunan rakyat yaitu sekitar 96,25\%. Lahan kopi rakyat, khususnya di Jawa Barat, sebagian besar menempati areal Perhutani dengan menjadikan kopi sebagai tanaman sela dari tanaman pokok kehutanan. Menurut data statistik Kopi Perum Perhutani Jawa Barat tahun 2019, luas pertanaman kopi di kawasan Perhutani mencapai sekitar 11.273 hektar. Penanaman kopi di lahan hutan menjadi kolaborasi antara petani dengan pihak Perhutani sehingga hutan dapat terjaga dengan baik dan petani mendapatkan hasil dari panen kopi (Dishut Jabar, 2019).

Permasalahan yang sering timbul pada budidaya kopi adalah semakin menurunnya intensitas cahaya matahari yang diterima tanaman kopi karena pertumbuhan kanopi tanaman penaung yang semakin melebar sehingga menghalangi cahaya jatuh ke bawah tanah. Namun, hal ini belum diteliti lebih lanjut apakah penaungan tersebut berpengaruh nyata terhadap pertumbuhan tanaman kopi muda (TBM) atau bahkan berpengaruh terhadap produksi tanaman menghasilkan (TM).

Meskipun tanaman kopi merupakan tanaman shade plant, namun penaungan yang terlalu tinggi atau terlalu rendah akan menurunkan produktivitas tanaman. Hasil penelitian Muliasari et al. (2016) menunjukkan bahwa naungan sebesar $74 \%$ menghasilkan pertumbuhan kopi arabika lebih baik, sedangkan hasil penelitian Bote et al. (2018) menunjukkan bahwa rasio luas daun pada tanaman kopi arabika dengan tingkat radiasi $30 \%$ berbeda nyata dibanding dengan tingkat radiasi $70 \%$ dan $100 \%$. Hal ini menunjukkan perbedaan intensitas radiasi matahari akan memberikan pengaruh yang berbeda pada pertumbuhan tanaman kopi.

Saat ini informasi respons fisiologis tanaman kopi terhadap intensitas naungan masih sangat terbatas sehingga perlu dilakukan penelitian lebih lanjut. Untuk lebih menjelaskan respons tanaman kopi terhadap perbedaan intensitas cahaya, maka perlu dilakukan penelitian pengaruh beberapa intensitas naungan terhadap pertumbuhan bibit beberapa varietas kopi untuk mengevaluasi respons fisiologis, berupa klorofil fluoresens, temperatur tajuk, serta respons agronomis berupa tinggi tanaman, indeks klorofil, dan luas daun dari dua kultivar kopi bebeda, sehingga diperoleh informasi kultivar kopi yang lebih tahan terhadap naungan.

\section{Bahan dan Metode}

Percobaan ini dilakukan pada bulan Maret sampai Juni tahun 2020 di Kebun Percobaan Fakultas Pertanian Universitas Padjadjaran, Jatinangor, Sumedang, Jawa Barat. Lokasi percobaan terletak pada ketinggian $\pm 750 \mathrm{~m}$ di atas permukaan laut (dpl) yang termasuk dataran medium.

Bahan yang akan digunakan dalam percobaan ini adalah bibit kopi arabika kultivar Lini S 795 dan Sigararutang, polybag berukuran $15 \mathrm{~cm} \times 25 \mathrm{~cm}$, pupuk urea, SP-36, dan $\mathrm{KCl}$. Alat yang digunakan dalam percobaan ini yaitu meteran, alat tulis, jangka sorong, thermal imaging camera (FLIR TG165), klorofilmeter (Apogee Instruments Inc), fluorescence meter (Hansatech Instrument), lux meter, higrometer, paranet dengan tingkat naungan $50 \%, 60 \%, 70 \%$ dan $80 \%$, serta plastik transparan.

Percobaan ini menggunakan Rancangan Petak Terbagi atau Split Plot Design, yang terdiri dari petak utama (main plot) berupa naungan dan anak petak (sub plot) berupa kultivar bibit kopi. Perlakuan terdiri dari main plot dengan lima taraf perlakuan intensitas naungan dan sub plot dengan dua taraf perlakuan, sehingga terdapat 10 perlakuan yang diulang sebanyak tiga kali sehingga terdapat 30 satuan percobaan. Taraf dari main plot adalah tanpa naungan, naungan paranet $50 \%, 60 \%$, $70 \%$, dan $80 \%$, 
sedangkan taraf dari sub plot adalah kultivar Lini S 795 dan Sigararutang. Setiap satuan percobaan ini terdiri dari tiga tanaman, sehingga jumlah total bibit tanaman kopi yang digunakan adalah 90 tanaman.

Berdasarkan rancangan analisis tersebut, maka disusun dalam tabel analysis of varians (ANOVA) yang dianalisis ragam menggunakan uji $\mathrm{F}$ pada taraf kepercayaan $95 \%$, dilanjutkan dengan uji Duncan pada taraf kepercayaan 95\% apabila terdapat perbedaan dalam perlakuan.

Pengamatan faktor fisiologis:

a. Klorofil fluoresens (Fv/Fm), pengukuran dilakukan dengan menggunakan alat fluorescence meter (Hansatech Instrument) pada pagi hari (Baker et al., 1989). Pengamatan dilakukan dengan mengukur daun paling atas dan dihitung pada umur 1, 6, 12 Minggu Setelah Perlakuan Naungan (MSP).

b. Suhu daun, pengukuran dilakukan dengan menggunakan alat thermal imaging camera (FLIR TG165), serta pengamatan dilakukan setiap dua hari sekali.

Pengamatan faktor agronomis:

a. Tinggi tanaman, diukur menggunakan meteran mulai dari pangkal batang sampai titik tumbuh tertinggi. Pengukuran tinggi dilakukan setiap dua minggu sekali yaitu 0 , 2, 4, 6, 8, 10, 12 MSP. Pertambahan tinggi tanaman dihitung dengan cara mengurangkan nilai tinggi tanaman pada umur tertentu dengan nilai tinggi tanaman 0 MSP.

b. Indeks klorofil daun dihitung dengan menggunakan alat klorofilmeter (Apogee Instruments Inc). Setiap sampel yang diambil merupakan daun terbesar pada setiap tanaman. Pengukuran dilakukan pada umur 1, 6, 12 MSP sehingga diketahui perbedaan indeks klorofil pada fase awal, pertengahan, dan akhir penelitian.

c. Luas daun $\left(\mathrm{cm}^{2}\right)$, dihitung dengan menggunakan cara memfoto daun pada kertas putih kemudian dihitung dengan bantuan aplikasi ImageJ (Glozer, 2008). Pengamatan dilakukan pada awal (0 MSP) dan akhir percobaan (12 MSP).

\section{Hasil dan Pembahasan}

Semua parameter pengamatan tidak memperlihatkan adanya interaksi antara kultivar dan intensitas naungan. Pengaruh mandiri memperlihatkan hasil pengamatan parameter klorofil fluoresens (Fv/Fm) menunjukkan naungan $80 \%$ pada awal tanaman, yaitu 1 MSP, dapat menurunkan tingkat stres dua kultivar kopi terhadap cahaya dibandingkan dengan perlakukan intensitas naungan lainnya. Hal ini dapat dilihat dengan nilai Fv/Fm lebih besar dibanding perlakuan tanpa naungan dan naungan $50 \%$ (Tabel 1). Sementara itu pada umur lanjut, yaitu $6 \mathrm{MST}$, pengaruh intensitas naungan ini tidak berbeda nyata di semua perlakuan naungan, kecuali pada perlakuan tanpa naungan di umur 12 MSP (Tabel 1).

Tabel 1. Klorofil fluoresens (Fv/Fm) kopi Lini S795 dan Sigararutang dengan intensitas naungan pada umur 1, 6, dan 12 MSP.

\begin{tabular}{lccc}
\hline \multirow{2}{*}{ Perlakuan } & \multicolumn{3}{c}{ Klorofil Fluoresens (Fv/Fm) } \\
\cline { 2 - 4 } N1 (0\%) & 1 MSP & 6 MSP & 12 MSP \\
N2 (50\%) & $0,475 \mathrm{~b}$ & $0,656 \mathrm{a}$ & $0,637 \mathrm{~b}$ \\
N3 (60\%) & $0,473 \mathrm{~b}$ & $0.609 \mathrm{a}$ & $0,709 \mathrm{a}$ \\
N4 (70\%) & $0,586 \mathrm{ab}$ & $0,669 \mathrm{a}$ & $0,731 \mathrm{a}$ \\
N5 (80\%) & $0,609 \mathrm{ab}$ & $0,682 \mathrm{a}$ & $0,742 \mathrm{a}$ \\
\hline K1 ( Lini S 795) & $0,574 \mathrm{a}$ & $0,679 \mathrm{a}$ & $0.719 \mathrm{a}$ \\
K2 (Sigarar utang) & $0,551 \mathrm{a}$ & $0,658 \mathrm{a}$ & $0,710 \mathrm{a}$ \\
\hline
\end{tabular}

Keterangan: Nilai rata-rata yang diikuti huruf yang berbeda pada kolom yang sama menunjukkan perbedaan nyata berdasarkan uji Duncan pada taraf nyata $5 \%$.

Tabel 1 menunjukkan bahwa intensitas naungan berpengaruh nyata terhadap kandungan klorofil fluoresens daun bibit kopi pada 1 dan 12 MSP, sedangkan kultivar kopi berpengaruh tidak nyata terhadap kandungan klorofil fluoresens daun bibit kopi. Pada pembibitan tanaman kopi, intensitas cahaya yang masuk ke dalam tempat pembibitan sangat mempengaruhi tingkat stress bibit kopi. Hal ini tidak ada pengecualian di kedua kultivar kopi.

Perlakuan naungan memperlihatkan nilai klorofil fluoresens $(\mathrm{Fv} / \mathrm{Fm})>0,7$ pada umur 12 MSP menandakan bibit dalan keadaan sehat, sedangkan nilai klorofil fluoresens $(\mathrm{Fv} / \mathrm{Fm})<$ 0,7 pada perlakuan tanpa naungan menandakan bibit dalam keadaan stres. Hal ini selaras dengan Bolhàr-Nordenkampf et al. (1989) yang 
menyatakan bahwa ketika tanaman menjaga kompleks fotosintesisnya utuh, rasio $\mathrm{Fv} / \mathrm{Fm}$ harus bervariasi antara 0,7 dan 0,8 .
Semua perlakuan intensitas naungan telah memperlihatkan tampilan fisiologis bibit kopi lebih baik dari perlakuan tanpa naungan, hal ini sejalan pula dengan nilai temperatur daun

Tabel 2. Temperatur daun bibit kopi kultivar Lini S795 dan Sigararutang dengan intensitas naungan pada umur 2, 4, 6, 8, 10, dan 12 MSP.

\begin{tabular}{lcccccc}
\hline \multirow{2}{*}{ Perlakuan } & \multicolumn{7}{c}{ Suhu Daun $\left({ }^{\circ} \mathrm{C}\right)$} \\
\cline { 2 - 7 } & $2 \mathrm{MSP}$ & $4 \mathrm{MSP}$ & $6 \mathrm{MSP}$ & $8 \mathrm{MSP}$ & $10 \mathrm{MSP}$ & $12 \mathrm{MSP}$ \\
\hline N1 (0\%) & $23,5 \mathrm{a}$ & $26 \mathrm{a}$ & $26,7 \mathrm{a}$ & $30,2 \mathrm{a}$ & $30,8 \mathrm{a}$ & $29,4 \mathrm{a}$ \\
N2 (50\%) & $23,1 \mathrm{~b}$ & $25 \mathrm{~b}$ & $25,4 \mathrm{~b}$ & $28,8 \mathrm{~b}$ & $29,6 \mathrm{~b}$ & $28,3 \mathrm{~b}$ \\
N3 (60\%) & $23 \mathrm{~b}$ & $24,6 \mathrm{~b}$ & $24,6 \mathrm{c}$ & $27,3 \mathrm{c}$ & $27,5 \mathrm{c}$ & $26,7 \mathrm{c}$ \\
N4 (70\%) & $22,8 \mathrm{bc}$ & $24,3 \mathrm{~b}$ & $23,3 \mathrm{~d}$ & $25,1 \mathrm{~d}$ & $24,9 \mathrm{e}$ & $25,6 \mathrm{~d}$ \\
N5 (80\%) & $22,6 \mathrm{c}$ & $24,5 \mathrm{~b}$ & $24,8 \mathrm{c}$ & $25,3 \mathrm{~d}$ & $25,8 \mathrm{~d}$ & $26,4 \mathrm{c}$ \\
\hline K1 ( Lini S 795) & $23 \mathrm{a}$ & $24,8 \mathrm{a}$ & $24,8 \mathrm{~b}$ & $27,3 \mathrm{a}$ & $27,7 \mathrm{a}$ & $27,2 \mathrm{a}$ \\
K2 (Sigarar utang) & $23,1 \mathrm{a}$ & $25 \mathrm{a}$ & $25,1 \mathrm{a}$ & $27,4 \mathrm{a}$ & $27,7 \mathrm{a}$ & $27,3 \mathrm{a}$ \\
\hline
\end{tabular}

Keterangan : Nilai rata-rata yang diikuti huruf yang berbeda pada kolom yang sama menunjukkan perbedaan nyata berdasarkan uji jarak berganda Duncan pada taraf nyata $5 \%$.

Tabel 3. Pertambahan tinggi bibit kopi koltivar Lini S795 dan Sigararutang dengan intensitas naungan pada umur 2, 4, 6, 8, 10, dan 12 MSP.

\begin{tabular}{|c|c|c|c|c|c|c|}
\hline \multirow{2}{*}{ Perlakuan } & \multicolumn{6}{|c|}{ Pertambahan Tinggi Bibit $(\mathrm{cm})$} \\
\hline & $2 \mathrm{MSP}$ & $4 \mathrm{MSP}$ & $6 \mathrm{MSP}$ & $8 \mathrm{MSP}$ & $10 \mathrm{MSP}$ & $12 \mathrm{MSP}$ \\
\hline N1 (0\%) & $1,65 \mathrm{a}$ & $2,65 \mathrm{ab}$ & $3,55 \mathrm{a}$ & $4,95 \mathrm{a}$ & $6,52 \mathrm{a}$ & $8,00 \mathrm{a}$ \\
\hline N2 (50\%) & $0,87 \mathrm{~b}$ & $1,96 \mathrm{c}$ & 3,14 a & 4,78 a & $6,58 \mathrm{a}$ & $8,60 \mathrm{a}$ \\
\hline N3 $(60 \%)$ & $1,55 \mathrm{a}$ & $2,58 \mathrm{ab}$ & $3,89 \mathrm{a}$ & 5,14 a & $6,79 \mathrm{a}$ & $9,20 \mathrm{a}$ \\
\hline N4 (70\%) & $1,69 \mathrm{a}$ & $2,83 \mathrm{a}$ & 4,31 a & $6,26 \mathrm{a}$ & $8,14 \mathrm{a}$ & 10,32 a \\
\hline N5 $(80 \%)$ & $1,36 \mathrm{a}$ & $2,33 \mathrm{bc}$ & 3,48 a & 5,25 a & $7,44 \mathrm{a}$ & 10,08 a \\
\hline K1 ( Lini S 795) & $1,46 \mathrm{a}$ & $2,58 \mathrm{a}$ & $4,00 \mathrm{a}$ & $5,54 \mathrm{a}$ & $7,64 \mathrm{a}$ & $9.62 \mathrm{a}$ \\
\hline K2 (Sigarar utang) & $1,37 \mathrm{a}$ & $2,36 \mathrm{a}$ & $3,35 \mathrm{a}$ & $5,01 \mathrm{a}$ & $6,83 \mathrm{a}$ & $8,87 \mathrm{a}$ \\
\hline
\end{tabular}

Keterangan : Nilai rata-rata yang diikuti huruf yang berbeda pada kolom yang sama menunjukkan perbedaan nyata berdasarkan uji jarak berganda Duncan pada taraf nyata $5 \%$.

untuk perlakuan naungan yang lebih rendah dari temperatur daun tanpa naungan (Tabel 2). Perlakuan intensitas naungan sebesar $70 \%$ memperlihatkan nilai temperatur daun lebih kecil dari perlakuan lainnya pada umur $6,8,10$ dan 12 MSP, menandakan nilai stres yang lebih ringan. Indeks stres tanaman dapat diukur dari nilai temperatur tajuk yang melebihi temperatur udara seperti yang telah dikembangkan pada model pengukuran temperatur tajuk jagung, kapas, dan zaitun (Zang et al., 2019).

Tanaman dapat mengurangi stress lingkungan dengan menjaga aktivitas membuka dan menutupnya stomata yang mengakibatkan proses metabolisme dapat berjalan dengan baik. Apabila stomata menutup menandakan ada gejala stres yang mengakibatkan proses metabolisme menurun, yaitu dengan menurunkan tingkat fiksasi $\mathrm{CO}_{2}$ di daun sehingga laju fotosintesis juga menurun. Chaves et al. (2003) menyatakan bahwa respons awal tanaman untuk melindungi tanaman dari kehilangan air dan kematian akibat kekeringan yaitu dengan menutup stomata dan daun yang menggulung. Konsekuensi penutupan stomata ini berakibat pada kenaikan temperatur permukaan daun. Peningkatan suhu kanopi tanaman selaras dengan menurunnya nilai konduktansi stomata seperti yang terjadi pada tanaman tebu yang mengalamai stress air (Soleh et al., 2017; Soleh et al., 2018).

Pada pengamatan morfologis tanaman, intensitas naungan dan kultivar kopi berpengaruh tidak nyata terhadap pertambahan tinggi bibit kopi pada pengamatan 2, 4, 6, 8, 10, dan 12 MSP (Tabel 3).

Perlakuan intensitas naungan sebesar $80 \%$ memperlihatkan nilai indeks klorofil lebih baik dari perlakuan lainnya pada umur pengamatan 12 MSP, sedangkan kultivar Lini S 795 memperlihatkan nilai indeks klorofil lebih baik dari kultivar Sigararutang pada umur 12 MSP (Tabel 4).

Tabel 4. Indeks klorofil bibit kopi kultivar Lini S795 dan Sigararutang dengan intensitas naungan pada umur 1, 6, dan 12 MSP.

\begin{tabular}{lccc}
\hline \multirow{2}{*}{ Perlakuan } & \multicolumn{3}{c}{ Indeks Klorofil } \\
\cline { 2 - 4 } N1 $(0 \%)$ & $1 \mathrm{MSP}$ & $6 \mathrm{MSP}$ & $12 \mathrm{MSP}$ \\
\hline $22,95 \mathrm{a}$ & $27,27 \mathrm{a}$ & $35,97 \mathrm{~b}$
\end{tabular}


ISSN: 1412-4718, eISSN: 2581-138x

\begin{tabular}{llll} 
N2 (50\%) & 19,61 a & 25,23 a & 26,88 c \\
N3 (60\%) & 23,14 a & 24,92 a & 35,98 b \\
N4 (70\%) & 21,84 a & 31,43 a & 31,43 bc \\
N5 (80\%) & 23,56 a & 34,37 a & 46,73 a \\
\hline K1 ( Lini S 795) & 24,44 a & 30,13 a & 39,78 a \\
K2 (Sigararutang) & 20,11 a & 27,15 a & 31,02 b
\end{tabular}

$\overline{\text { Keterangan : Nilai rata-rata yang diikuti huruf yang }}$ berbeda pada kolom yang sama menunjukkan perbedaan nyata berdasarkan uji jarak berganda Duncan pada taraf nyata 5\%.

Pada pengamatan luas daun, perlakuan naungan memperlihatkan hasil lebih baik daripada perlakuan tanpa naungan pada umur pengamatan 12 MSP (Tabel 5). Sejalan dengan hasil penelitian Robakowski et al. (2003) yang menunjukkan bahwa penurunan luas daun seiring dengan meningkatnya intensitas cahaya. Hal ini disebabkan tanaman kopi merupakan shade plant yang tumbuh baik di bawah naungan.

Tabel 5. Luas daun bibit kopi kultivar Lini S795 dan Sigararutang dengan intensitas naungan pada umur 0 dan 12 MSP.

\begin{tabular}{llc}
\hline \multirow{2}{*}{ Perlakuan } & \multicolumn{2}{c}{ Luas Daun $\left(\mathrm{cm}^{2}\right)$} \\
\cline { 2 - 3 } N1 (0\%) & MSP & $12 \mathrm{MSP}$ \\
N2 (50\%) & $13,90 \mathrm{a}$ & $19,32 \mathrm{c}$ \\
N3 (60\%) & $15,74 \mathrm{a}$ & $26,23 \mathrm{ab}$ \\
N4 (70\%) & $14,74 \mathrm{a}$ & $29,55 \mathrm{a}$ \\
N5 (80\%) & $14,76 \mathrm{a}$ & $28,75 \mathrm{a}$ \\
\hline K1 ( Lini S 795) & $15,10 \mathrm{a}$ & $21,22 \mathrm{bc}$ \\
K2 (Sigararutang) & $19,42 \mathrm{a}$ & $25,92 \mathrm{a}$ \\
\hline
\end{tabular}

Keterangan : Nilai rata-rata yang diikuti huruf yang berbeda pada kolom yang sama menunjukkan perbedaan nyata berdasarkan uji jarak berganda Duncan pada taraf nyata $5 \%$.

Intensitas naungan sebesar $80 \%$ memperlihatkan indeks klorofil lebih tinggi (Tabel 4), sehingga aktivitas fotosintesis dipastikan akan lebih baik daripada kondisi tanpa naungan. Fotosintesis tanaman kopi di bawah naungan menunjukkan nilai yang lebih tinggi dibanding tanaman kopi tanpa naungan (Bote and Struik, 2011). Begitu pula respons luas daun dalam kondisi naungan memperlihatkan respons yang lebih baik daripada tanpa naungan
(Tabel 5) karena tanaman kopi merupakan shade plant yang menghendaki naungan tertentu untuk proses pertumbuhan dan perkembangan. Parameter luas daun dan Fv/Fm dapat menunjukkan kesehatan tanaman (Kitao et al., 2000; Malone et al., 2002). Luas daun berkaitan dengan kapasitas fotosintesis sedangkan Fv/Fm memperlihatkan tingkat stress tanaman. Hal ini mengindikasikan tanaman kopi dalam perlakuan naungan mampu melakukan proses metabolisme dengan baik untuk tumbuh dan berkembang, dibandingkan tanpa naungan dan atau naungan intensitas yang lebih kecil.

\section{Kesimpulan}

Naungan merupakan kondisi lingkungan yang penting bagi pertumbuhan tanaman kopi. Intensitas naungan $70 \%$ merupakan perlakuan yang lebih baik terhadap parameter tinggi tanaman dan suhu daun. Sedangkan naungan $80 \%$ hanya baik untuk respons indeks klorofil. Perlakuan varietas kopi Lini S 795 memberikan nilai terbaik terhadap parameter tinggi tanaman, indeks klorofil, klorofil fluoresens, dan suhu daun.

\section{Daftar Pustaka}

Badan Pusat Statistik. 2018. Statistik Kopi Indonesia 2017. BPS Press

Bolhàr-Nordenkampf, H. R., S. P. Long, N. R. Baker., G. Öquist., U. Schreider, and E. G. Lechner. 1989. Chlorophyll fluorescence as probe of the photosynthetic competence of leaves in the field: a review of current instrument. Functional Ecology 3(4): 497514

Bote, A. D. and P. Stuik. 2011. Effects of shade on growth, production and quality of coffea (Coffea arabica) in Ethiopia. Jurnal of Horticulture and Forestry, 3(11): 336-341.

Bote, A. D., Z. Zana., F. L. Ocho, and V. Jan. 2018. Analysis of coffee (Coffea arabica L.) performance in relation to radiation level and rate of nitrogen supply II. Uptake and distribution of nitrogen, leaf photosynthesis and first bean yields. European Journal of Agronomy (92):107-114 
Chaves, M. M., J. P. Maroco, and J. S. Pereira. 2003. Understanding plant responses to drought-from genes to the whole plant. Functional Plant Biology 30(3): 239 -264.

Direktorat Jenderal Perkebunan. 2018. Outlook Komoditas Pertanian Sub Sektor Perkebunan Kopi tahun 2017. Kementerian Pertanian. Jakarta. Dapat diakses http://epublikasi.setjen.pertanian.go.id/d ownload/file/402-outlook-kopi-2017

Dishut Jabar. 2019. Statistik Kehutanan Jawa Barat tahun 2018. Dapat diakses http://dishut.jabarprov.go.id/data/Statisti ik/Statistik\%202018.pdf

Glozer, K. 2008. Protocol for leaf image analysis surface area. Dapat diakses http://ucanr.edu/sites/fruittree/files/493 25.pdf.

Kitao, M., L. T. Thomas, K. Takayoshi, T. Hiroaki, and M. Yutaka. 2000. Susceptibility to photoinhibition of three deciduous broad leaf tree species with different successional traits raised under various light regimes. Plant Cell Environment, 23(1): 81- 89.

Malone, S., D. A. Herbert, and D. L. Holshouser. 2002. Relationship between Leaf Area Index and yield in Double-crop and full-season soybean systems. Journal Ecological Entomology., 95(5): 945-951.
Muliasari, A. A., A. Wachjar, dan Supijatno. 2016. Optimasi intensitas naungan pada pertumbuhan bibit kopi arabika (Coffea arabica L.). Prosiding Seminar Nasional Pendidikan Vokasi Indonesia 2016.

Robakowski, P., P. Montpied, and E. Dreyer 2003. Plasticity of morphological and physiological traits in response to different levels of irradiance in seedling of silver fir (Abies alba Mill.) Trees, (Berl.). 7: 431-441.

Sekretariat Jendral Perkebunan. 2016. Outlook Kopi Subsektor Perkebunan. Pusat Data dan Sistem Informasi Pertanian. Kementerian Pertanian

Soleh, M. A., M Ariyanti, I. R. Dewi, and M. Kadapi. 2018. Chlorophyll fluorescence and stomatal conductance of ten sugarcane varieties under waterlogging and fluctuation light intensity. Emirates Journal of Food and Agriculture. 30(11): 935-940.

Soleh, M. A., R. Manggala, Y. Maxiselly, M. Ariyanti dan I. R. D. Anjarsari. 2017. Respons konduktansi stomata beberapa genotipe tebu sebagai parameter toleransi terhadap stress abiotik. Kultivasi. 13: 490493.

Zhang L., Y. Niu, H. Zhang, W. Han, G. Li, J. Tang, and X. Peng. 2019. Maize Canopy Temperature Extracted From UAV Thermal and RGB Imagery and Its Application in Water Stress Monitoring. Frontiers in Plant Science. 10: 1270. 